\title{
Pelatihan Stimulasi Literasi Anak Usia Dini bagi Guru Taman Kanak-kanak di Kecamatan Nanggalo, Kota Padang
}

\author{
Yulsyofriend $^{1}$, Yaswinda $^{2}$ \\ Pendidikan Guru Pendidikan Anak Usia Dini \\ Universitas Negeri Padang
}

\begin{abstract}
ABSTRAK
Pembiasaan literasi yang tidak sesuai dengan perkembangan anak akan memberikan dampak negatif bagi perkembangan anak usia dini selanjutnya. Ikatan Guru Taman Kanak-kanak di kecamatan Nanggalo menyadari bahaya yang mengancam anak didik mereka jika memberikan stimulasi literasi yang tidak sesuai dengan perkembangan anak dapat mebahayakan anak, namun di sisi lain masih banyak guru-guru Taman Kanak-kanak yang belum memahami stimulasi literasi yang tepat untuk anak usia dini dan belum terampil melaksanakannya. Tujuan kegiatan Pengabdian pada masyarakat ini adalah untuk meningkatkan pemahaman stimulasi literasi dan keterampilan stimulasi literasi guru-guru Taman kanak-kanak di Kecamatan Nanggalo kota Padang. Hasil penilaian media literasi terhadap peserta sebagai berikut: 23,08 \% peserta mendapatkan kategori baik sekali dan 53,84\% memperoleh kategori baik serta ada 15,38\% dalam kategori cukup.
\end{abstract}

Kata kunci : stimulasi literasi, anak usia dini, guru TK

\section{PENDAHULUAN}

Budaya literasi pada dasarnya harus dimulai dari usia dini, segala sesuatu yang ditumbuhkan secara wajar dalam kehidupan anak di rumah dan di lembaga Pendidikan Anak Usia Dini, termasuk di Taman Kanak-kanak. Pembiasaan literasi yang tidak sesuai dengan perkembangan anak akan memberikan dampak negatif bagi perkembangan anak usia dini selanjutnya. Pengenalan literasi (membaca dan menulis) pada anak usia dini merupakan hal yang penting. Menurut Graff (2006) literacy adalah kemampuan untuk membaca dan menulis (able to read and write), sedangkan orang yang mampu keduanya disebut literat. Menurut Suyadi (2010) mengemukakan bahwa kemampuan litreasi dapat diperkenalkan atau diajarkan kepada anak usia dini sejak anak berada dalam kandungan. Jika dikaitkan dengan pengajaran di PAUD, maka Guru PAUD memegang peranan dalam mengembangkan budaya literasi anak usia dini. 
Badan Program Pembangunan dalam lembaga PBB (United Nations Development Programme/UNDP) dalam laporan Human Development Report 2016 mencatat, Indeks Pembangunan Manusia (IPM) Indonesia pada 2015 berada di peringkat 113, turun dari posisi 110 di 2014. Sejalan dengan hal itu, hasil literasi Programme for International Students Assessment (PISA) 2015 baru saja dirilis 6 Desember 2016, hasil tes dan evaluasi PISA 2015 performa siswa-siswi Indonesia masih tergolong rendah. Berturut-turut rata-rata skor pencapaian siswa-siswi Indonesia untuk sains, membaca, dan matematika berada di peringkat 62, 61, dan 63 dari 69 negara yang dievaluasi. Peringkat dan rata-rata skor Indonesia tersebut tidak berbeda jauh dengan hasil tes dan survey PISA terdahulu pada tahun 2012 yang juga berada pada kelompok penguasaan materi yang rendah. Data-data tersebut sungguh mengkwatirkan para tim pengabdian masyarakat sebagai akademisi.

Sementara itu, persoalan membaca anak usia dini saat ini merupakan fenomena di masyarakat. Para orang tua yang memiliki anak usia dini khususnya di Taman Kanak-Kanak (TK) khawatir anak-anaknya tidak mampu mengikuti pelajaran di sekolahnya nanti jika sedari awal belum dibekali keterampilan membaca dan menulis sehingga memimta guru TK mengajarkan atau memberikan les tambahan membaca dan menulis untuk anak mereka. Joyce and Chalhoun (2011) mengemukakan bahwa anak belajar literasi atau bahasa secara alamiah. Pada periode anak mulai dari lahir sampai dengan usia enam tahun, anak-anak memperoleh pengetahuan tentang membaca dan menulis tidak melalui pengajaran, tetapi melalui perilaku yang sederhana dengan mengamati dan berpartisipasi pada aktivitas yang berkaitan dengan literasi. Dengan mengamati orang yang melakukan aktivitas literasi dan berpartisipasi dengan aktivitas tersebut maka anak akan memperoleh kemampuan yang merupakan prasyarat penting untuk mengembangkan membaca konvensional.

Bersadarkan wawancara dengan ketua IGTK Nanggalo, kota Padang, banyak Guru Nanggalo yang merasa kewalahan memenuhi tuntutan orang tua murid agar lulusan TK bisa membaca. Padahal, Morrison (2012) mengemukakan bahwa proses membaca dan menulis pada anak usia dini dipandang sebagai proses alami ; menulis bagi anak usia dini merupakan proses yang diikuti oleh anak secara alami jauh sebelum mereka bersekolah. Lebih lanjut ia mengaktakan bahwa kemampuan membaca dan menulis merupakan salah satu tujuan pendidikan nasional yang penting tidak hanya bagi anak usia dini tetapi bagi semua orang.

Salah satu strategi yang dapat digunakan dalam mengembangkan kemampuan membaca anak usia dini adalah dengan pendekatan pengalaman berbahasa. Menurut Dhieni (2009), pendekatan pengalaman berbahasa dapat diberikan dengan menerapkan konsep DAP 
(Developmentally Aproppriate Practice). Menciptakan suasana bermain pada anak-anak dapat pula dilakukan dengan menggunakan media atau alat permainan, baik media gambar atau yang lain. Pendekatan ini dapat pula dilakukan dengan menggunakan media bermain, seperti kartu, gambar, puzzle, flashcard, dan lain sebagainya.

Berdasarkan penelitian yang telah dilakukan oleh Dharmawan (2017) disimpulkan bahwa pembelajaran literasi/keaksaraan menggunakan media big book meningkat. Pembelajaran ini dapat dilaksanakan dengan bimbingan dan arahan dari guru agar penggunaan media big book ini dapat berjalan dengan optimal. Pembelajaran yang diberikan secara terus menerus akan meningkatkan kemampuan keaksaraan anak untuk bekal di jenjang yang lebih tinggi. Sejalan dengan penelitian ini, hasil penelitian Rismawati, Wirya, dan Asril(2015) menunjukkan bahwa terjadi peningkatan kemampuan bahasa lisan anak kelompok B2 di TK Mutiara Singaraja setelah diterapkan metode bercakap-cakap dengan media big book sebesar $19,15 \%$. Hal ini terlihat dari peningkatan rata-rata persentase kemampuan bahasa lisan anak pada siklus I sebesar $65,55 \%$ yang berada pada kategori sedang. Pada siklus II rata-rata persentase kemampuan bahasa lisan anak mengalamani peningkatkan menjadi sebesar $84,70 \%$ yang berada pada kategori tinggi. Jadi dengan demikian dapat disimpulkan bahwa metode bercakap-cakap dengan media big book dapat meningkatkan kemampuan bahasa lisan anak kelompok B2 semester II tahun pelajaran 2014/2015 di TK Mutiara Singaraja. Hasil-hasil penelitian diatas, menguatkan tim pengabdian masyakat memeberikan pelatihan stimulasi literasi anak kusia dini dengan mengajarkan pembuatan media bigbokk sebagai media literasi anak usia dini bagi guru-guru di kecamatan Nangalo, kota Padang.

Nanggalo adalah sebuah kecamatan di kota Padang, Sumatera Barat, Indonesia. Sebelum bergabung dengan Kota Madya Padang pada tahun 1980, Nanggalo adalah sebuah Kenagarian dalam Kecamatan Koto Tangah, Kabupaten Padang-Pariaman. Keadaan geografis, sebelah utra berbatasan dengan kecamatan Koto Tangah, sebelah selatan berbatasan dengan Padang Utara, Sebelah barat berbatasan dengan Padang Utara dan sebelah timur berbatasan dengn kecamatan Kuranji. Luas daerah 8,07 $\mathrm{Km}^{2}$. Kecamatan Padang Utara, sebelah barat berbatasan dengan Samudera Hindia, sebelah timur berbatasan dengan Kecamatan Padang Timur dan Padang Barat dan Nanggalo, sebelah utara berbatasan Kecamatan Koto tangah.

\section{METODE}

Kegiatan pelatihan stimulasi literasi dilaksanakan pada tanggal 28 dan 29 Agustus 2017 di TK Kartika 1-61 Lapai. Mitra yang terlibat adalah lembaga Ikatan Guru TK (IGTK) 
kecamatan Nanggalo kota Padang. Kegiatan ini diikuti dua puluh guru TK. Kegiatan ini menggunakan dua metode, yaitu: Ceramah/seminar dan Praktek langsung. Untuk pemberian informasi digunakan metode ceramah dimana para nara sumber menyajikan makalah dan setelah itu dilakukan tanya jawab. Selanjutnya setelah satu bulan setelah pelatihan tersebut, dilakukan monitoring dua TK secara langsung untuk melihat pelaksanaan/penerapan stimulasi literasi yang telah diperoleh dalam pelatihan. Untuk guru TK yang lainnya dilakukan monitoring dengan menggunakan lembar penilaian media literasi berupa bigbook yang dibuat guru-guru di kecamatan Nanggalo.

Mitra terlibat dalam menentukan anggotanya yang akan dilibatkan dalam kegiatan pengabdian masyarakat ini, mulai dari menentukan tempat pemberian pelatihan, memberikan undangan pada 20 guru TK dari kecamatann Nanggalo, menyebarkan dan mengumpulkan angket penerapan hasil pelatihan kepada guru-guru TK yang telah ikut pelatihan stimulasi literasi dua bulan setelah kegiatan pelatihan dilaksanakan.

Selesai monitoring dilanjutkan menganalisis data. Perolehan nilai dan interpretasi keberhasilan pembuatan media literasi yang disusun adalah perolehan nilai peserta yang diinterpretasikan seperti pada Tabel 2.berikut.

Tabel 2. Interpretasi Nilai

\begin{tabular}{|l|l|}
\hline Perolehan nilai & Interpretasi Keberhasilan \\
\hline $85-100$ & Baik sekali \\
\hline $75-84$ & Baik \\
\hline $60-74$ & Cukup \\
\hline $40-59$ & Kurang \\
\hline $0-39$ & Kurang sekali \\
\hline
\end{tabular}

(Nurgiantoro, 2001:399)

\section{HASIL DAN PEMBAHASAN}

Adanya kegiatan pelatihan stimulasi literasi untuk anak usia dini bagi guru-guru di Kecamatan Nanggalo, Kota Padang yang dilakukan tim pengabdian sangat disambut dengan antusias oleh guru-guru. Pada hari pertama pelatihan, (sesi seminar), seluruh peserta dibagi 
menjadi 4 kelompok dan masing- masing-masing kelompok dimnta membuat media literasi anak usia dini berupa bigbook. Pemateri 1 dan 2 disampaikan oleh Dra. Yulsyofriend, M.Pd. Kelas serta pentingnya PTK sedangkan pemateri 3 disampaikan oleh Dr. Yaswinda, M.Pd. Kegiatan ini juga melibatkan dua orang mahasiswa PG PAUD UNP yang berperan sebagai istuktur di sesi praktek.

Dalam pelaksanaan pelatihan terlihat anggota kelompok bersemangat mengikuti program pelatihan yang diberikan. Masing-masing anggota kelompok saling bekerjasama membuat media literasi. Hari kedua pelatihan, telah dihasilkan 4 media stimulasi literasi untuk anak usia dini seperti yang terlihat pada gambar 1. Selanjutnya dilakukan simulasi praktek penggunaan media stimulasi yang telah dibuat. Para guru mempraktekkan pelaksanaan stimulasi literasi perkelompok.

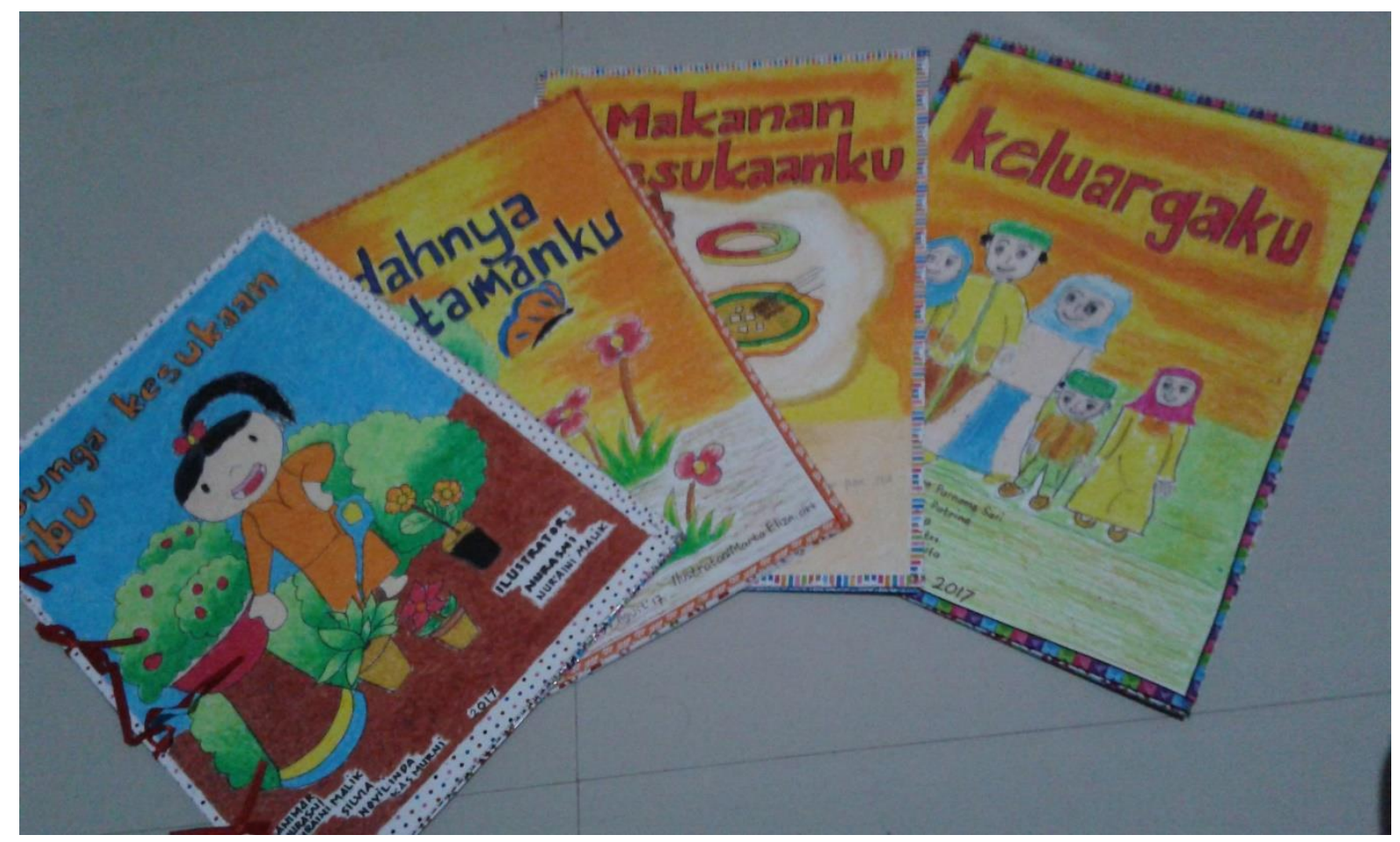

Gambar 1. Media Stimulasi Literasi Karya Kelompok Guru TK Keamatan Nanggalo

Setelah dua bulan pelaksanaan pelatihan, semua perserta pelatihan diminta mengumpulkan media literasi yang dihasilkan di TK masing-masing. Dari duapuluh peserta, terdapat 13 guru yang berhasil menyelasaikan media literasi berupa bigbook atau hanya $65 \%$ peserta. Hasil rekapitulasi penialaian bigbook terdapat pada tabel 1 . 
Tabel 1. Hasil Penilaian Media Stimulasi Literasi Guru TK di Kecamatan Nanggalo

\begin{tabular}{|c|c|c|c|c|c|c|c|c|}
\hline \multirow{2}{*}{ No } & \multicolumn{6}{|c|}{ Skor Penilaian Bigbook } & Jumlah & Total \\
\cline { 2 - 9 } & $\begin{array}{c}\text { Jenis } \\
\text { huruf }\end{array}$ & $\begin{array}{c}\text { Ukuran } \\
\text { huruf }\end{array}$ & $\begin{array}{c}\text { Cover } \\
\text { buku }\end{array}$ & Kerapian & Ilustrasi & $\begin{array}{c}\text { Konsistensi } \\
\text { pengulangan } \\
\text { kata }\end{array}$ & & Skor \\
\hline 1 & 9 & 9 & 8 & 8 & 8 & 7 & 49 & 81,67 \\
\hline 2 & 8 & 8 & 8 & 8 & 8 & 8 & 48 & 80,00 \\
\hline 3 & 8 & 8 & 10 & 8 & 9 & 9 & 52 & 86,67 \\
\hline 4 & 8 & 8 & 9 & 8 & 8 & 7 & 48 & 80,00 \\
\hline 5 & 6 & 6 & 7 & 7 & 7 & 9 & 42 & 70,00 \\
\hline 6 & 6 & 6 & 9 & 8 & 7 & 7 & 43 & 71,67 \\
\hline 7 & 9 & 9 & 10 & 8 & 8 & 10 & 54 & 86,67 \\
\hline 8 & 8 & 8 & 8 & 8 & 7 & 9 & 48 & 80,00 \\
\hline 9 & 9 & 7 & 8 & 8 & 8 & 8 & 48 & 80,00 \\
\hline 10 & 9 & 9 & 10 & 9 & 9 & 10 & 56 & 93,33 \\
\hline 11 & 8 & 8 & 7 & 7 & 8 & 8 & 46 & 76,67 \\
\hline 12 & 9 & 8 & 8 & 8 & 8 & 9 & 50 & 83,33 \\
\hline 13 & 8 & 8 & 10 & 7 & 7 & 9 & 49 & 81,67 \\
\hline
\end{tabular}

Selesai monitoring dilanjutkan menganalisis data. Perolehan nilai dan interpretasi keberhasilan pembuatan media literasi yang disusun adalah perolehan nilai peserta yang diinterpretasikan seperti pada Tabel 3.berikut.

Tabel 3. Distribusi Keberhasil Pelatihan / Pembuatan Media Literasi

\begin{tabular}{|l|l|l|l|}
\hline Perolehan nilai & Frekuensi & Persentasi (\%) & Interpretasi Keberhasilan \\
\hline $85-100$ & 3 & 23,08 & Baik sekali \\
\hline $75-84$ & 7 & 53,84 & Baik \\
\hline $60-74$ & 2 & 15,38 & Cukup \\
\hline $40-59$ & 0 & 0 & Kurang \\
\hline $0-39$ & 0 & 0 & Kurang sekali \\
\hline
\end{tabular}


Dari hasil distribusi keberhasilan pelatihan terlihat hasil yang 23,08\% media yang dibuat mendapat kategori baik sekali dan 53,84 \% memperoleh kategori baiki. Ada 15, 38\% media stimulasi literasi yang mendapatkan kategori penilaian cukup. Hal ini berarti, peserta pelatihan $72,73 \%$ peserta telah dapat menunjukkan kemampuan yang baik dan baik sekali dalam membuat media stimulasi literasi berupa bigbook. Hasil ini cukup menggembirakan, diharapkan anak-anak muncul budaya literat di TK. Joyce and Chalhoun (2011) mengemukakan bahwa anak belajar literasi atau bahasa secara alamiah. Pada periode anak mulai dari lahir sampai dengan usia enam tahun, anak-anak memperoleh pengetahuan tentang membaca dan menulis tidak melalui pengajaran, tetapi melalui perilaku yang sederhana dengan mengamati dan berpartisipasi pada aktivitas yang berkaitan dengan literasi. Dengan mengamati orang yang melakukan aktivitas literasi dan berpartisipasi dengan aktivitas tersebut maka anak akan memperoleh kemampuan yang merupakan prasyarat penting untuk mengembangkan membaca konvensional. Sejalan dengan hal tersebut, Morrison (2012) mengemukakan bahwa proses membaca dan menulis pada anak usia dini dipandang sebagai proses alami ; menulis bagi anak usia dini merupakan proses yang diikuti oleh anak secara alami jauh sebelum mereka bersekolah. Lebih lanjut ia mengaktakan bahwa kemampuan membaca dan menulis merupakan salah satu tujuan pendidikan nasional yang penting tidak hanya bagi anak usia dini tetapi bagi semua orang.

\section{KESIMPULAN}

Berdasarkan hasil pelaksanaan pelatihan maka memberikan rumusan hasil pelatihan dalam simpulan berikut ini:

1. Pelatihan diikuti oleh 20 peserta berasal dari para guru TK dari beberapa TK yang berada di kecamatan Nanggalo, Kota Padang berlangsung sangat dinamis, antusias, dan bersemangat.

2. Peserta pengabdian telah mendapatkan pengetahuan dan keterampilan tentang membuat media literasi untuk anak usia dini selama pelatihan. Dalam pelaksanaan pelatihan, semua peserta berpatisipasi aktif menbuat media literasi anak usia dini dan berhasil menciptakan 4 media literasi secara berkelompok.

3. Penerapan hasil pelatihan oleh guru-guru di kecamatan Nanggalo dalam kategori Cukup, maksudnya, hanya $65 \%$ peserta yang berhasil menyelesaikan bigbook 
dalam rentang waktu 2 bulan setelah pelatihan. Hasil penilaian media literasi terhadap bigbook masing-masing peserta yang berhasil menyelesaikan pembuatan big booknya sebagai berikut 23,08 \% media yang dibuat mendapat kategori baik sekali dan 53,84\% memperoleh kategori baik serta ada 15, 38\% dalam kategori cukup.

\section{DAFTAR PUSTAKA}

Dhieni, Nurbiana, dkk. 2009. Metode Pengembangan bahasa. Jakarta: Universitas Terbuka

Graff, Harvey J. 2006 Literacy. Microsoft@ Encarta ${ }^{\circledR}$ [DVD]. Redmond, WA: MicrosoftCorporation

Joyce, B. Weil, M. Calhoun, E. 2011. Models Of Teaching (Model-Model Pembelajaran). Yogyakarta: Pustaka Belajar

Morrison Goerge S.2011. Dasar-Dasar Pendidikan Anak Usia Dini (PAUD). Edisi kelima. Jakarta: Indeks

Suyadi.2010. Psikologi Belajar PAUD, Pedagogia, Jogjakarta

Fauzi, Yuliyana. Ranking Indeks Pembangunan Manusia Indonesia Turun ke-113 , CNN Indonesia | Rabu, 22/03/2017; https://www.cnnindonesia.com/ekonomi/20170322182446 -78-202081/ranking-indeks-pembangunan-manusia-indonesia-turun-ke-113/

Ni Nyoman Rismawati ., Drs. Nyoman Wirya ., Nice Maylani Asril, S.Psi.,M.Psi. Penerapan Metode Brcakap-cakap dengan Media Big Book untuk Meningkatkan Kemampuan Bbahasa Lisan Anak, Jurnal Pendidikan Anak Usia Dini. Vol 3 no 1 (2015).

Darmawan, Ridha. 2017. Penggunaan Media Big Book untuk Meningkatkan Kemampuan Keaksaraan Anak Kelompok B di TK Al Fadholi Malang https://ejournal.undiksha.ac.id/index.php/JJPAUD/article/view/5856

Http Dinas Pendidikan kota Padang/ diknas-padamng -org https://www.oecd.org/pisa/pisa-2015-results-in-focus.pdf Y Yulsyofriend, Y Yaswinda, Z Zulminiati - Pedagogi: Jurnal IImu Pendidikan, 2013. PELAKSANAAN MODEL REGGIO EMELIO PADA PEMBELAJARAN ANAK USIA DINI DI TAMAN KANAK-KANAK ASSYOFA PADANG. Pedagogi: Jurnal IImu Pendidikan. Jilid 13. No 1. Halaman 52-57 